\title{
Recepcija G. K. Chestertona u hrvatskoj katoličkoj periodici 1921.-1945.
}

\author{
Vladimir Lončarević*
}

\begin{abstract}
Sažetak
Od kada se, od 1903., pod vodstvom krčkog biskupa Antuna Mahnića razvijao Hrvatski katolički pokret, pratilo ga je bujanje katoličkog tiska, počevši od pokretanja časopisa Hrvatska straža za kršćansku prosvjetu 1903., prvog hrvatskog filozofijskog časopisa. Taj pokret zauzimao se za rekristijanizaciju Hrvatske, pa su konvertiti na katolicizam među europskom inteligencijom, kojih je od početka 19. stoljeća broj neprestano rastao, u hrvatskom katoličkom tisku nerijetko isticani kao znak i poruka duhovne renovacije katolicizma u Europi, ali i njegove prihvatljivosti za intelektualnu elitu, što je nerijetko bilo osporavano iz raznih krugova liberalne ili socijalističke, tj. komunističke inteligencije. Među njima bio je i niz intelektualaca s engleskoga govornog područja, među njima i Gilbert Keith Chesterton. Članci o njemu objavljivani su od 1921. do 1945., kada je silom komunističke represije obustavljeno izlaženje katoličkog tiska. Tekstovi se mogu podijeliti u dva korpusa: a) članci o Chestertonu (životopisi, interpretacije $i$ prikazi djela) $i$ b) prijevodi na hrvatski jezik (novele, eseji, izvadci iz knjiga). Vremenski, članci su najviše grupirani oko dvaju ključnih događaja: Chestertonova obraćenja i smrti.
\end{abstract}

Ključne riječi: G. K. Chesterton, recepcija, obraćenje, katolička periodika, 1921.-1945.

\section{Uvod}

»Točnost i sigurnost u najvažnijim pitanjima modernog života nalazim jedino u katoličkoj crkvi i stoga sam postao katolik (Uredništvo, 1923a, 205). Tako Chestertonove riječi iz razgovora s neimenovanim američkim novinarom prenosi isusovačka revija Život u članku Gilbert-Keith Chesterton 1923. godine, otprilike godinu dana nakon Chestertonova prihvaćanja katolicizma.

Od kada se od 1903. pod vodstvom krčkoga biskupa Antuna Mahnića razvijao Hrvatski katolički pokret (Krišto, 2004), pratilo ga je i bujanje katoličkoga tiska,

* Dr. sc. Vladimir Lončarević, viši znanstveni suradnik, Ured Predsjednice Republike Hrvatske. Adresa: Pantovčak 241, 10000 Zagreb, Hrvatska. E-adresa: vladimir.loncarevic31@gmail.com 
počevši od pokretanja prvoga našega filozofijskoga časopisa Hrvatska straža za kršćansku prosvjetu (1903.), studentskoga časopisa Luč: revija za misao i život hrvatskog katoličkog đaštva (1905.), dnevnika Riječke novine (1912.) i književnoga časopisa Hrvatska prosvjeta (1914.) do brojnih drugih novina, tjednika, časopisa, godišnjaka, kalendara, almanaha i dr. Pokret je imao cilj rekristijanizaciju Hrvatske, tada već politički i kulturno uvelike nagriženu liberalizmom. Utoliko su katolički konvertiti među europskom inteligencijom, kojih je od početka 19. stoljeća broj neprestano rastao, bili u neku ruku znak i poruka duhovne renovacije katolicizma u svijetu, ali i njegove prihvatljivosti za intelektualnu elitu, što je nerijetko bilo osporavano iz raznih krugova liberalne ili socijalističke, tj. komunističke inteligencije. Među njima bio je i niz intelektualca s engleskoga govornoga područja. Tako se tih godina, posebice nakon Prvoga svjetskoga rata nadalje u hrvatskom katoličkom tisku našao znatan broj tekstova o Johnu Henryu Newmanu, Hilaireu Bellocu, Robertu Hughu Bensonu, Thomasu Stearnsu Eliotu, Gerardu Manleyu Hopkinsu, Cliveu Staplesu Lewisu i drugima, a među njima i o Gilbertu Keithu Chestertonu.

Rođen je u Campden Hillu kod Londona 29. svibnja 1874. godine. Kršten je u Anglikanskoj crkvi. Pohađao je umjetničku školu i satove književnosti na Londonskom sveučilišnom kolegiju, no nije završio nijedan fakultet. S vremenom je postao sve više privržen kršćanskim uvjerenjima, što je kulminiralo njegovim obraćenjem i ulaskom u Katoličku crkvu, kojoj je formalno pristupio 30. srpnja 1922. godine. Radio je kao novinar i književni kritičar. Godine 1902. dobio je tjednu kolumnu u listu Daily News, a 1905. tjednu kolumnu u The Illustrated London News, za koju je pisao trideset godina. Volio je debate i često se u njih upuštao, među ostalim s Georgeom Bernardom Shawom i Herbertom Georgeom Wellsom. Godine 1931. BBC ga je pozvao na niz radijskih razgovora. Vanjštinom osobit, krupne pojave, obično je nosio ogrtač i zgužvan šešir, sa štapom u ruci i cigarom u ustima, po čemu je najčešće vizualno upamćen, a za što su vezane razne anegdote. Preminuo je 14. lipnja 1936. u svojem domu u Beaconsfieldu, gdje je pokopan na katoličkom groblju. Među osamdesetak njegovih knjiga najpoznatija je Orthodoxy (Pravovjerje), knjiga kojoj se ove 2018. godine navršava 110 godina od prvoga izdanja, da bi potom u desetcima izdanja bila objavljena diljem svijeta na brojnim jezicima, a čak dvaput na hrvatskom (2001. i 2015.). Objavio je oko četiri tisuće različitih članaka. Navodi se da je utjecao na engleskog književnika Clivea Staplesa Lewisa, ruskog Aleksandra Solženjicina, američkog nadbiskupa i pisca Fultona Johna Sheena, teologa Hansa Ursa von Balthasara i filozofa Étiennea Gilsona (usp. Torbarina, 1942). ${ }^{1}$

1 Josip Torbarina oslanja se samo na engleske izvore. U natuknici navodi sva važnija djela u engleskim naslovima. Ističe kako je »g. 1922. stupio je u katoličku crkvu, kojoj je od rane mladosti naginjao, tako da idejno nema velike razlike između njegovih djela pisanih prije i poslije obraćenja. [...] Djela mu se odlikuju paradoksalnim i ekstravagantnim stilom, kojim izrazuje i promiče 'katolički liberalizam', te borbeno reagira na spise svojih starijih suvremenika u književnosti, Wellsa i Shawa. [...] U esejima o vjerskim pitanjima i suvremenoj politici Ch. "na nekonvencionalan način brani konvencionalnost', te je stoga dobio nadimak 'majstor paradoksa' " (Torbarina, 1942). 
Članci o njemu u Hrvatskoj objavljivani su do 1945. poglavito u katoličkoj periodici, kada je, nakon što su komunisti preuzeli vlast, sav katolički tisak obustavljen, samim time i moguća afirmativna recepcija. Cilj je ovoga rada prikazati recepciju Chestertona u hrvatskoj katoličkoj periodici u razdoblju od početka 20. stoljeća do 1945. godine, konkretno u razdoblju 1921. — 1945. S obzirom na autorstvo, mogu se podijeliti u dva korpusa: a) članci o Chestertonu i b) prijevodi Chestertonovih tekstova na hrvatski jezik. ${ }^{2}$

Članci o Chestertonu mogu se pak podijeliti na životopisne članke, interpretacije njegovih misli i stajališta te na prikaze njegovih djela.

Prijevodi tekstova mogu se podijeliti na prijevode novela, eseja i izvadaka iz knjiga. Pjesma je samo jedna, u sklopu članka u reviji Život 1923. godine. ${ }^{3}$ Potrebno je napomenuti da su u razdoblju do 1945. na hrvatski jezik prevedene knjige Četvrtak (Sarajevo: Hrvatska knjižara, 1920.), Tajna oca Browna (Zagreb: Zabavna biblioteka, 1928.) i Otac zapadne kulture Sv. Toma Akvinski (Zagreb: Istina, 1939.). Nakon 1945. njegova djela na hrvatskom jeziku nisu tiskana sve do 1988., kada je u Borgesovoj biblioteci u izdanju Grafičkoga zavoda Hrvatske objavljena knjiga priča Apolonovo oko. Nakon toga tek 1996. objavljena je nova knjiga Nevinost oca Browna te nakon toga do danas tridesetak naslova njegovih djela, od detektivskih priča i eseja do knjige o sv. Franji Asiškom, ponovljenoga izdanja knjige o sv. Tomi, Pravovjerje te jednog od središnjih njegovih djela, zbirke filozofskih eseja Vječni čovjek.

\section{1. Članci o Chestertonu}

Chesterton postaje tema na hrvatskom jezičnom području početkom dvadesetih godina, a u katoličkoj periodici 1921., kada je u časopisu Hrvatska prosvjeta objavljen prijevod novele Modri križ iz ciklusa priča o velečasnom Brownu u prijevodu Antuna Šimčika. ${ }^{4}$ Tekst je popraćen prikazom glavnoga urednika Ljubomira Marakovića ${ }^{5}$ G. K. Chesterton. Maraković ga naziva: »jedan od najsjajnijih

2 Veći dio bibliografije može se naći u: Ujević, 1959. Autor ovog članka ručno je pregledao kartice o Chestertonu u Predmetnom kazalu Leksikografskog zavoda Miroslav Krleža, pri čemu je ustvrdio da nije upisana predmetnica za ovdje navedenu referenciju: Uredništvo, 1922. Predmetnice samim time nema ni u: Ujević, 1959. Manji dio bibliografije sadržava rad: Peričić, 1997.

3 Pjesma Magarac prevedena je na srpski i slovenski, a nekoliko pjesama na slovenski jezik.

4 Antun Šimčik (27. siječnja 1893. - 27. rujna 1970.), pisac, urednik, leksikograf, prevoditelj i lektor. Rođen je u mjestu Zářičí u Chropyně kod Kroměříža u Moravskoj. Od 1896. živio je u Ivanovčanima kod Bjelovara, a od 1906. u Zagrebu. Godine 1928. diplomirao je slavistiku, romanistiku i latinski jezik na Filozofskom fakultetu u Zagrebu. Objavljivao je članke, studije i rasprave u brojnim katoličkim i građanskim listovima i časopisima te je prevodio, uz ustalo za izdanja Hrvatskog književnog društva Sv. Jeronima. Umro je u Zagrebu (Lončarević, 2016).

5 Ljubomir Maraković (17. lipnja 1887. - 22. veljače 1959.), književni, scenski i filmski kritičar, književni povjesničar i teoretik te urednik. Rođen je u Topuskom. Maturirao je na isusovačkoj gimnaziji u Travniku. Germanistiku i slavistiku studirao je u Beču, gdje je 1909. doktorirao. Nakon studija radio je kao srednjoškolski profesor u Banjoj Luci i Zagrebu, a kratko 1944. — 1945. na Visokoj pedagoškoj školi kao sveučilišni profesor. Bio je urednik časopisa Hrvatska prosvjeta 
pisaca današnje Engleske, autor 'Heretika' i 'Ortodoksije', veliki borac protiv organiziranog materijalizma, pisac 'Četvrtka' « (Maraković, 1921, 379), čiji je prijevod, podsjeća, 1920. tiskala Hrvatska tiskara u Sarajevu. Zaključujući prikaz njegova literarnog rada i stila, Maraković zaključuje:

Chesterton je velika moralna energija, usamljena i poštovanja vrijedna u dobi koja ne može da dopuže više no do nekog humanitarnog majmuna, koja brblja o svjetskom miru, dok sve ide u susret prevratu [...] sjajni rvač Gospoda Boga, taj lojalni, srdačni muž, prijatelj vina i opojenosti, taj bezbrižni, slobodni i veseli čovjek (Maraković, 1921, 379).

\section{1. Članci o obraćenju}

Članak Obraćenje G. K. Chestertona donosi dnevnik Narodna politika 1922. godine, koji neimenovani autor započinje prenoseći obavijest iz engleskih katoličkih novina The Tablet o Chestertonovu krštenju u Katoličkoj crkvi 30. srpnja 1922. u Beaconsfieldu. Pisac izvješćuje o njegovu spisateljsko-uredničkom radu, prijateljstvu s Hilaireom Bellocom, stavivši obraćenje u kontekst prethodnih apologija katolicizma (John Henry Newman, Toma Moore), ali i teškoća koje prate katolike u Engleskoj (Uredništvo, 1922, 2).

Obraćenje G. K. Chestertona članak je Stjepana Podolšaka ${ }^{6}$ kojim je u časopisu Hrvatska prosvjeta 1922. godine na četiri i pol stranice komentirao njegovu konverziju. Nazvavši ga »duhoviti pisac«, naglasio je kako je Chesterton time povukao »krajnje životne konsekvencije iz svog tačnog i dosljednog umovanja« (Podolšak, 1922, 468). Podolšak njegovo obraćenje značenjem smatra jednakim Newmanovu. Nakon toga prenijet je veći dio članka iz engleskog katoličkog tjednika The Tablet, s Podolšakovim zaključkom da svaka njegova riječ može biti i naša vlastita.

Najveći članak povodom njegova obraćenja objavila je isusovačka revija Život 1923. pod naslovom Gilbert-Keith Chesterton: (Engleski Solovjev). ${ }^{7} \mathrm{Na}$ deset stranica dan je u važnijim crtama Chestertonov životopis i popis najvažnijih do tada tiskanih njegovih djela, s kritičkim primjedbama, uz zaključak da je njegovo obraćenje (navodeći kao njezin nadnevak 30. srpnja 1922.) kruna svih obraćenja na katolicizam u Engleskoj, kojih se broj tada procjenjivao na oko 12.000 godišnje (usp. Gahs, 1929). U sklopu članka je i prijevod izvadaka iz nekoliko njegovih

(1919. - 1940.). Objavljivao je u katoličkoj i građanskoj periodici. Autor je prve hrvatske teorije književnosti Žetva. Umro je u Zagrebu (Lončarević, 2009).

6 Stjepan Podolšak (9. rujna 1901. - 7. srpnja 1984.), pravnik, publicist i prevoditelj. Rođen je u Čretu kod Krapinskih Toplica. Poslije završene klasične gimnazije u Zagrebu upisao je 1921. Pravni fakultet, diplomirao 1925. i doktorirao 1927. godine. Bio je glavni urednik časopisa Luč (1922. - 1923.) i član redakcije Narodne politike, novina Hrvatske pučke stranke. Godine 1940. bio je odgovorni urednik tada pokrenutog lista Hrvat u tuđini, glasila Društva Sv. Rafaela za zaštitu hrvatskih iseljenika. Pisao je u katoličkoj periodici. Prevodio je s engleskoga novele kršćanske spisateljice Enis Maud Dinnis. Umro je u Zagrebu (Lončarević, 2011d).

7 Članak u tekstu nije potpisan, a u pregledu sadržaja stoji N. N. (non nominatus). Budući da su se tako redovito potpisivali urednici časopisa Život, vjerojatno je autor članka tadašnji urednik Ante Alfirević. 
djela te prijevod pjesme Mudraci s Istoka, što pokazuje da je autor članka dobro poznavao njegov rad. Ističe kako je od njegova »svega nastojanja [...] najzamašnije [...] ono koje ga je dovelo na područje filozofije i apologije «(Uredništvo, 1923, 201), s knjigom Pravovjerje kao glavnim djelom. Autor, uz pohvale, ne propušta reći da Chesterton ipak tek treba usvojiti ne samo »katoličko shvaćanje i osjećanje u svemu, nego i adekvatnu katoličku terminologiju« (Uredništvo, 1923, 204).

\section{2. Članci o smrti}

Više tekstova objavljeno je povodom njegove smrti 1936. godine. U središnjem katoličkom glasilu dnevniku Hrvatska straža u broju 143 objavljena je vijest o njegovoj smrti, kraći životopis, uz spomen važnijih djela (Uredništvo, 1936). Neimenovani pisac prenosi potom dio teksta posvećen njemu i Bellocu iz članka Ljube Čuvala Katolički književnici u Engleskoj iza Shakespearea, objavljenom prethodno u almanahu Stopama otaca (Čuvalo, 1934-1935).

Nekrolog, s crtežom Chestertonova profila, napisao je Josip Andrić ${ }^{8}$ (1936) u tjedniku Obitelj pod naslovom Jedan od najvećih katoličkih pisaca: Nakon nedavne smrti engleskoga pisca Gilberta Keitha Chestertona. Andrić posebice ističe njegovu privrženost irskoj borbi za neovisnost, o čemu je, kao i o Irskoj, Andrić često pisao, objavivši i knjigu. Osim toga, posebice ističe Chestertonovu »duhovitost, koja je za njegovo književno djelo tako značajna«. Spominje prijevod na hrvatski jezik knjige Tajna oca Browna, napomenuvši da Obitelj u počast piscu donosi u istom broju jednu »novelu s tim ocem Brownom « (Andrić, 1936). U istom broju tjednik Obitelj donosi prijevod članka Verboyea iz pariških dnevnih katoličkih novina La Croix naslovljenoga Lik G. K. Chestertona (Verboye, 1936). Kasnije u istom godištu objavljena je njegova polemika s Shawom iz pera Hesketha Pearsona ${ }^{9}$ (1936) pod naslovom Shaw contra Chesterton, uz isti crtež što je bio objavljen uz Andrićev nekrolog.

Istim povodom godine 1937. u franjevačkoj Novoj reviji objavljen je urednički tekst Šta je veliki književnik Chesterton našao u katoličkoj Crkvi, navodeći kao razlog oslobođenje od grijeha, što daje samo Katolička crkva (Uredništvo, 1937).

U Glasniku sv. Ante Padovanskoga 1937. članak Gilbert Keith Chesterton potpisan je pseudonimom Myr. ${ }^{10}$ Zanimljivo je što u bilješci autor daje uputu čitatelji-

8 Josip Andrić (14. ožujka 1894. - 7. prosinca 1967.), književnik, urednik, novinar, prevoditelj, skladatelj, glazbenik, zborovođa, melograf i pravnik. Rođen je u selu Bukinu kod Bačke Palanke. Pohađao je Trgovački fakultet u Pragu, dopisno bečku glazbenu školu Konservatorium te studirao skolastičku filozofiju na Teološkom fakultetu u Innsbrucku. Od 1913. do 1917. u Zagrebu je studirao pravo te doktorira 1920. godine. Bio je urednik časopisa Luč (1914. - 1916.) i dopredsjednik Hrvatske pučke stranke (1919. - 1929.). Od 1919. do 1927. uređivao je Seljačke novine, a od 1921. do 1954. izdanja Hrvatskog književnog društva Sv. Jeronima. Početkom rata kraće vrijeme proveo je u logoru Dachau. Objavio je više putopisa i brojne članke u katoličkoj periodici. Sastavio je Slovačku slovnicu 1942. te napisao 1944. prvu povijest slovačke glazbe. Umro je u Zagrebu (Lončarević, 2011c).

9 Hesketh Pearson (Hawford, 20. veljače 1887. — London, 9. travnja 1964.), britanski glumac, pisac $\mathrm{i}$ intendant.

10 Uza sva nastojanja, nije bilo moguće utvrditi identitet autora. 
ma da njegovo ime treba čitati »Gilbert Kith Čestetn« (Myr, 1937, 263). Članak, popraćen Chestertonovom fotografijom, pisan je jednostavnim informativnim stilom, sukladno obrazovnom stupnju većine čitatelja (tzv. pučko glasilo). »Borio se za paradokse paradoksima« (Myr, 1937, 364), ističe pisac naglasivši glavnim odlikama njegova utjecaja vedrinu i ustrajnost u traženju i svjedočenju istine te njegovo divljenje srednjemu vijeku i Katoličkoj crkvi, polemike s Shawom i Wellsom, zaključivši da je taj »pjesnik, apologet, socijalni radnik « čovjek kojim se »trebamo ponositi i koga, još više, trebamo nasljedovati« (Myr, 1937, 366).

\subsection{Prikazi Chestertonovih djela}

Više je prikaza Chestertonovih djela. U dnevniku Narodna politika godine 1927. trogirski svećenik Ivo Delalle ${ }^{11}$ u članku Filozofija Chestertona prikazao je talijansko izdanje L'Ortodossia. Delalle, ustvrdivši slikovito kako je Chesterton spomenutu knjigu napisao na svojem putu u Damask, pa mu se mogu oprostiti neke engleske ekstravagancije, piše: »Chesterton je velik u svojim romanima, ali pravi Chesterton nalazi se u njegovim filozofskim djelima«(Delalle, 1927, 2). Ortodoksijom taj »uvjereni katolik, tradicionalista u strogom smislu riječi traži da moderni svijet svede na katoličku stazu i da probudi kršćansku svijest «, istaknuvši da su »glavne karakteristike ovog djela [...] humorizam, jasnoća stila, ugodno razlaganje, logičnost u dedukcijama « (Delalle, 1927, 2). Ukratko, to je »remekdjelo [...] najljepši plod filozofske aktivnosti ovog pisca« (Delalle, 1927, 4).

Knjiga o sv. Tomi prikazana je više puta, kako francusko izdanje 1935., tako hrvatsko 1939. godine. Francusko izdanje prikazali su dominikanac Hijacint Bošković ${ }^{12}$ i novinar Stjepan Tomičić. ${ }^{13}$

11 Ivo Delalle (13. studenoga 1892. — 31. siječnja 1962.), svećenik, književnik i povjesničar umjetnosti. Rođen je u Trogiru, maturirao na klasičnoj gimnaziji u Splitu, studirao bogosloviju u Zadru, a za svećenika je zaređen 1915. u Splitu. Diplomirao je 1929. kršćansku arheologiju na Papinskom institutu za kršćansku arheologiju u Rimu te doktorirao 1930. godine. Objavio je brojne članke u katoličkoj periodici. Trogir, vodič po njegovoj historiji, umjetnosti $i$ životu, prvi kulturno-povijesni vodič o nekom hrvatskom gradu, objavio je 1936. godine. Potaknuo je osnivanje Društva za proučavanje i zaštitu starina Radovan, Kulturnog društva Berislavić te Društva za unapređenje turizma. Umro je u Trogiru (Lončarević, 2011a).

12 Hijacint Bošković (15. travnja 1900. - 26. prosinca 1947.), svećenik i filozof. Rođen je, kršten imenom Ante, u Selcima na Braču. Studij filozofije započeo je 1919. u Dubrovniku, a 1920. nastavio na rimskom Angelicumu. Za svećenika je zaređen 1924., a doktorirao 1928. godine. Pokrenuo je 1929. nakladu Istina i časopis Duhovni život. Uz članke u Duhovnom životu i drugoj katoličkoj periodici, najpoznatije mu je djelo Filozofski izvori fašizma i nacionalnog socijalizma. Umro je u Starom Gradu na Hvaru (Miščin, 2011).

13 Stjepan Tomičić (26. svibnja 1919. - 28. srpnja 1999.), novinar i publicist. Rođen je u Otočcu. U Zagrebu i Parizu studirao je političke nauke te apsolvirao na Pravnom fakultetu u Zagrebu, gdje je 1938. počeo surađivati u katoličkom dnevniku Hrvatska straža. U svibnju 1945. probio se do Beča, potom u Salzburg, gdje je promijenio ime u Alfons Dalma te započeo novu novinarsku karijeru u Salzburger Nachrichten. Od 1954. do 1967. bio je glavni urednik münchenskog lista Münchner Merkur i stalni komentator bečkog dnevnika Die Presse. Godine 1967. imenovan je glavnim urednikom ÖRF-a, a od 1974. do 1986. radio je kao dopisnik ÖRF-a iz Rima i Vatikana. Umro je u Beču (Lončarević, 2017). 
Bošković je svoj prikaz objavio u časopisu Duhovni život 1935. pod naslovom Chesterton o sv. Tomi, bilješkom upućujući na francusko izdanje. ${ }^{14}$ Iako će, kaže na početku, mnogima naizgled čudno biti što »ekstravagantni engleski pisac, za koga bi se moglo u prvi mah misliti da svojim kurioznim paradoksima nema ništa zajedničko s usklađenim linijama harmonijskog i intelektualističkog filozofskog sistema sredovječnog mislioca, laća se biografije 'muklog vola Sicilije' « (Bošković, 1935, 248), s druge je strane to razumljivo iz potrebe da se sv. Tomu predstavi kao »čovjeka naših dana « (Bošković, 1935, 249). Može se primijetiti da se u daljnjem tekstu Bošković, budući tomist, "izgubio" u sv. Tomi, pa još samo u posljednjem odlomku spominje završnu Chestertonovu rečenicu (Bošković, 1935, 251).

Vezano za francuski prijevod, Tomičić u listu Hrvatska straža 1935. u članku G. K. Chesterton o Sv. Tomi Akvinskom preporučuje knjigu riječima: »Uistinu će svaki katolički intelektualac dobro učiniti ako pročita ovu studiju o velikom katoličkom filozofu« (Tomičić, 1935). Isti je pisac u časopisu Hrvatska prosvjeta 1936. u članku Ličnosti $i$ vjekovi, uz prikaz više knjiga, ponovno pisao o tom francuskom izdanju, utvrdivši da Chesterton piše »žestoko, živahno, s mnogo snage i zanosa « (Tomičić, 1936, 67).

U kulturno-političkom časopisu Hrvatska smotra objavio je 1939. Drago Ćepulić ${ }^{15}$ prikaz knjige Otac zapadne kulture Sv. Toma Akvinski. Naglašava kako Chesterton u svojem prikazu poentira na činjenici da je Toma spojio vjeru i razum, što nam nedostaje u našem vremenu, slikovito zaključivši da su Chestertonove misli »medicina naših dana« (Ćepulić, 1939, 424).

Uz najavu skoroga tiska knjige o sv. Tomi, dnevnik Hrvatska straža godine 1939. donosi pod naslovom Čas sv. Tome "prve stranice te interesantne studije jednoga od najumnijih katoličkih književnika o najvećem katoličkom filozofu « (Chesterton, 1939a, bilješka). Isti dnevnik nakon izlaska knjige donosi ulomak iz knjige pod naslovom Približavanje tomizmu, istaknuvši, uz preporuku za čitanje, da je Chesterton »laganim i briljantnim stilom [...] napisao [...] blistavu i sažetu studiju«, u kojoj na »lagan, sugestivan i suvremen način izlaže i najteže filozofske probleme« (Chesterton, 1939b, bilješka). Taj hrvatski prijevod popraćen je i u časopisu Luč godine 1940. kratkim prikazom G. K. Chesterton: Otac zapadne kulture Sv. Toma Akvinski (preveo s engleskoga Josip Blažina) ${ }^{16}$ (R., 1940).

14 G. K. Chesterton, Saint Thomas d'Aquin. Version française de M. Vox. Paris: Plon.

15 Drago Ćepulić (3. siječnja 1893. - 1. ožujka 1976.), filozof i publicist. Rođen je u Novom Vinodolskom. Pohađao je Gornjogradsku klasičnu gimnaziju u Zagrebu, a maturirao 1911. u Bjelovaru. Diplomirao je 1914. romanistiku i filozofiju u Beču. Doktorirao je 1920., postavši prvi doktor romanistike na Zagrebačkom sveučilištu. Objavio je nekoliko knjiga uspomena i filozofskih eseja, osobito o francuskim piscima i filozofima, te više desetaka raznih članaka. Umro je u Zagrebu (Lončarević, 2006).

16 Josip Blažina (14. ožujka 1905. - 13. prosinca 1987.), svećenik, urednik, publicist i prevoditelj. Rođen je u Križišću. Pohađao je pomorsku akademiju u Bakru, kratko radio kao činovnik na državnim željeznicama, no osjetivši svećeničko zvanje, otišao na studij bogoslovije te je 1932. zaređen za svećenika. Bio je urednik katoličkog tjednika Istina (1934. — 1941.), dnevnika Hrvatski glas (1941.), tjednog ilustriranog magazina Nedeljne vijesti (1942.), a zatim do podkraj rata uređivao je »hrvatski šaljivi i zabavni tjednik « Šilo. Objavio je brojne humoreske i druge članke u 


\subsection{Ostali članci}

Između članaka motivski obilježenih tim dvaju središnjim momentima Chestertonova života više je različitih koji ističu neki sadržaj ili značajku njegova života i mišljenja. Tako je u isusovačkom časopisu Život objavljena njegova radijska polemika s Bernardom Shawom i lady Rhondda ${ }^{17}$ o radu žena (S., 1927).

Franjevačka Nova revija 1928. donosi tekst Bože Vuce ${ }^{18}$ Slavni engleski obraćenik G. K. Chesterton i ateizam, u kojem prenosi glavne naglaske njegovih stajališta o ateizmu, sa zaključkom da materijalizam, po Chestertonu, »nije dostojan razumna čovjeka nego luđaka « (Vuco, 1928, 78). U istom časopisu objavljen je godine 1932. kraći tekst Jedna umjesna opaska o svjetskom razoružanju $i$ miru, prenoseći njegovu misao o pravednom i nepravednom ratu, no ne navodeći vrelo (B., 1932).

Opširan članak G. K. Chesterton Vilka Riegera ${ }^{19}$ nalazimo u križarskom tjedniku Nedjelja početkom 1930. godine. Rieger suprotstavlja Chestertona Wildeu i Shawu, istaknuvši irsko podrijetlo sve trojice i njihov »sličan način pointiranja u paradoksima «, naglašava njegovu sklonost vjerskim pitanjima i traganje za savršenstvom vjere, koju napokon nalazi u Katoličkoj crkvi. Predstavlja ga čovjekom koji mrzi svaku silu i tiraniju, a posebice nad razumom. On je za nj prije svega književnik, primarno esejist, navodeći neka njegova djela puna »veselosti i dobre volje, baroka i paradoksa«. Zanimljivo je što, uz ostalo, uočava kako je Chesterton svoje detektivske priče začinio religioznom, konkretno "pastoralnom notom « (Rieger, 1930).

U organizacijsko-literarnom časopisu hrvatskoga katoličkog đaštva (studenata) Luč tiskana je, popraćena crtežom Chestertona, u dva dijela 1931. novela Markiz Marne, a prati je u 3. broju prikaz mladog novinara Ive Bogdana ${ }^{20}$ Chester-

katoličkoj periodici. U svibnju 1945. povlači se u Austriju, da bi završio u Južnoj Americi. Pisao je u više emigrantskih listova i časopisa. Umro je u Cochabambi u Boliviji (Lončarević, 2011b).

17 Margaret Haig Mackworth, druga vikontesa Rhondda (1883. - 1958.), engleska sufražetkinja.

18 Božo Vuco (24. prosinca 1897. - 18. siječnja 1984.), svećenik, urednik i pisac. Rođen je u Vojniću. Nakon školovanja na učilištima Provincije, zaređen je za svećenika u Makarskoj 1921. godine. Nastavio je studij na Sveučilištu u Fribourgu (Švicarska), gdje je 1924. doktorirao. Uređivao je franjevački časopis Nova revija, objavio više knjiga i mnoštvo članaka. Umro je u Makarskoj (Hoško i dr., 2010, s. v. Vuco, Božo).

19 Vilko Rieger (11. studenoga 1911. - 6. lipnja 1998.), ekonomist, novinar, diplomat, političar i publicist. Rođen je u Zagrebu. Diplomirao je 1937. na Ekonomsko-komercijalnoj visokoj školi u Zagrebu (danas Ekonomski fakultet) te 1938. i doktorirao. Nakon odlaska u emigraciju u svibnju 1945. predavao je na katoličkom ženskom učilištu Marywood College u Scrantonu (Pennsylvania), kasnije professor emeritus i član Hrvatske akademije Amerike (Croatian Academy of America). Objavio je prije, tijekom i nakon Drugog svjetskog rata desetak knjiga i brojne članke u hrvatskoj domovinskoj i iseljeničkoj periodici. Umro je u Greenwoodu, Južna Karolina (SAD) (Stuparić, 1997, s. v. Rieger, Vilko).

20 Ivo Bogdan (30. rujna 1907. - 18. kolovoza 1971.), novinar, urednik, publicist i političar. Rođen je u Suđurađu na Šipanu. Pohađao je Trgovačko-pomorsku akademiju u Dubrovniku, gdje je uređivao katolički list $\check{Z} a r$ te pisao u dubrovačkom glasilu Hrvatske pučke stranke Narodna svijest. Studirao je na zagrebačkoj Ekonomsko-komercijalnoj visokoj školi. Bio je urednik časopisa Luč 1927., a zatim od 1929. član uredništva dnevnika Hrvatska straža te od 1933. odgovorni urednik istoimenog tjednika. U sklopu Hrvatskog književnog društva Sv. Jeronima s I. Lendićem 
ton Gilbert Keith. Bogdan ističe njegov borbeni duh, stavivši naglasak na njegovu prozu »punu paradoksa «, napominjući da mu pripovijesti obilježavaju »romantičke groteske«, zaključivši da pripada među one koji su »najbliži idealu javnog radnika, kakovog hoće da odgoji naš katolički pokret« (Bogdan, 1931-1932).

Kontekstualno o Chestertonu piše Ljubo Čuvalo, tada na studiju u Londonu, u članku Katolički književnici u Engleskoj iza Shakespearea, objavljenom u almanahu hercegovačke franjevačke omladine Stopama otaca, posvetivši njemu i Bellocu više od jedne stranice od ukupno osam. Čuvalo ističe kako se za nj može reći »da je bio katolikom dok je još bio članom anglikanske crkve«. Navodi njegove važnije knjige te prijateljstvo s Bellocom, zaključivši kako se od njih »ne da rastaviti današnji nagli razvoj katolicizma u Britaniji« (Čuvalo, 1934-1935, 107).

\section{Prijevodi}

Osim prikazbenih članaka, prevedeno je i objavljeno u katoličkoj periodici više njegovih tekstova, među kojima i novela. Godine 1921. donosi Hrvatska prosvjeta prijevod Antuna Šimčika novele Prostota oca Browna: Modri križ (Chesterton, 1921).

Već je spomenut prijevod novele Markiz Marne 1931. u časopisu Luč (Chesterton, 1931-1932). Prijevod crtice The Wind and the Trees tiskan je čak triput. Prvi put objavljen je u tjedniku Obitelj 1929. pod naslovom Vjetar i drveće, bez navođenja prevoditelja (Chesterton, 1929). U časopisu Hrvatska straža crtica je tiskana dvaput: 1930. pod naslovom Vjetar i drvlje u prijevodu O. Sivjanovića (svećenik Petar Sivjanović?) (Chesterton, 1930) te ponovno 1935. pod naslovom Vjetar i drveće u drukčijem prijevodu, no bez navođenja prevoditelja (Chesterton, 1935). U tjedniku Obitelj objavljene su 1936. "kriminalne novele" Grimizna vlasulja (Chesterton, 1936b) i Salata pukovnika Craya (Chesterton, 1936c) u prijevodu Vladimira Sironića. ${ }^{21}$

Od eseja prvi je tiskan u časopisu Hrvatska prosvjeta 1922. pod naslovom $G$. Bernard Shaw: (Iz Heretika) (Chesterton, 1922), koji je, bez napomena, preveo Antun Šimčik. Nakon Chestertonove smrti tjednik Obitelj donosi prijevod tek-

pokrenuo niz Moderna socijalna kronika (MOSK). Godine 1939. bio je suutemeljitelj dnevnika Hrvatski narod, od 1941. ravnatelj, a od 1943. urednik. U veljači 1942. s Tijasom Mortigjijom pokrenuo je kulturno-politički tjednik Spremnost. U svibnju 1945. emigrirao je, a od 1947. živio u Argentini, gdje je 1960. - 1968. bio glavni urednik čaopisa Studia Croatica i njegovih posebnih izdanja. Ubili su ga agenti Udbe (Lončarević, 2014).

21 Vladimir Sironić (14. lipnja 1894. - 13. veljače 1985.), pravnik, urednik i publicist. Rođen je u Trvižu kod Pazina. Godine 1912. maturirao je na Hrvatskoj gimnaziji u Pazinu te pošao na bogosloviju u Gorici, no 1913. upisao je pravo u Zagrebu. Godine 1920. nastavio je studij, a 1923. vratio se u Istru i preuzeo tajništvo Političkoga društva za Hrvate i Slovence u Istri, uredništvo časopisa Pučki prijatelj i uredništvo društvovnih izdanja Društva Sv. Mohora za Istru u Trstu, a 1929. preuzeo je uredništvo Istarskog lista. Prisiljen je 1931. napustiti Istru i doći u Zagreb. Pisao je u katoličkoj periodici, gdjekad pod pseudonimom Čakavac. Uređivao je dvotjednik Gore srca (1946. — 1947.). Do 1965. bio je tajnik i urednik Istarskog književnog društva, uređujući Istarsku Danicu. Umro je u Puli, a pokopan u rodnom Trvižu (Lončarević, 2015). 
sta Zašto sam katolik? bez navođenja vrela i prevoditelja (Chesterton, 1936d). Dominikanski časopis Duhovni život donosi 1939. novi prijevod istoga članka, prevedena s njemačkoga iz Lampingove knjige Ljudi koji se vraćaju Crkvi, ${ }^{22}$ bez navođenja prevoditelja (Chesterton, 1939d). Godine 1936. Obitelj objavljuje članak Gospodin Bernard Shaw bez navođenja prevoditelja (Chesterton, 1936a).

Nakon objavljivanja hrvatskoga prijevoda knjige o sv. Tomi Hrvatska straža objavila je prijevode dijelova knjige pod naslovima Čas sv. Tome (Chestreton, 1939a) i Približavanje tomizmu (Chesterton, 1939b), koju je uredništvo popratilo bilješkom, uz ostalo istaknuvši: »G. K. Chesterton je u sebi sintetizirao novinara i filozofa.« Ocijenivši njegovu smrt kao »velik gubitak za englesku publicistiku uopće, a za suvremeni katolicizam napose«, autor bilješke ističe: »Laganim i briljantnim stilom, oštroumnim opaskama, opasnim te strjelovitim analogijama i aluzijama na suvremene prilike i suvremene ličnosti napisao je G. K. Chesterton blistavu i sažetu studiju o ličnosti i filozofiji Sv. Tome Akvinskoga«, preporučivši to »krasno djelo, bez kojega ne bi smio biti nitko, tko hoće da ga smatraju u najmanju ruku katoličkim inteligentom «(Chesterton, 1939b, 4). Iste godine objavljuje Hrvatska straža i članak G. B. Shaw koga Nijemci rabe u svojoj propagandi: G. $K$. Chesterton o Shawu i njegovu gledanju na svijet, život i pojave u društvu, kojega su dio prijevodi knjige Heretik (Chesterton, 1939c).

Posljednji Chestertonov tekst, esej Znanje i ludost objavljen je u križarskom tjedniku Nedjelja kroz tri broja početkom 1945., bez navođenja prevoditelja i popratnih bilježaka (Chesterton, 1945). To je ujedno najdulji njegov esej u hrvatskoj periodici do 1945. godine.

Pjesma je prevedena samo jedna, u sklopu članka Gilbert-Keith Chesterton: (Engleski Solovjev) (Uredništvo, 1923, 201-202).

Zanimljivo će još biti napomenuti da $L u c ̌$ u jednom od posljednjih brojeva ratne 1942. donosi kao moto Chestertonovu misao »...radost, ta tajna uspjeha kršćanstva« (Uredništvo, 1942).

\section{Zaključak}

Riječ je ukupno o trideset osam tekstova u dvadeset pet godina, od toga devetnaest posebnih članaka o Chestertonu i dva kontekstualna, te sedamnaest prijevoda njegovih tekstova, od kojih su dva ista u dvama prijevodima pod sličnim naslovima (Zašto sam katolik? i Zašto sam postao katolik?) te tri ista teksta u trima prijevodima (dva pod naslovom Vjetar i drveće i jedan Vjetar i drvlje). U časopisu Obitelj objavljeno je osam tekstova, Hrvatska straža ima sedam priloga, Hrvatska prosvjeta pet, Luč četiri, Nova revija tri, zatim Duhovni život, Nedjelja, Život i Narodna politika po dva te po jedan Hrvatska smotra, Glasnik sv. Antuna Padovanskoga i Stopama otaca. Možda se broj radova ne doima velikim, no treba imati na umu da engleski jezik još nije bio svjetski u današnjem smislu riječi, pa 
ni hrvatska kultura u cjelini, tako ni katolička, nije u to vrijeme primarno pratila englesko govorno područje, koliko primjerice njemačko, francusko ili talijansko, koja su Hrvatima tradicijski bila bliska. U europskim zemljama tih jezičnih kultura hrvatska je katolička inteligencija vrlo često studirala, a studiji u Engleskoj ili putovanja u nju mogu se nabrojati na prste jedne ruke. Više zanimanja bilo je za Irsku kao tada eminentno katoličku zemlju.

U hrvatskoj katoličkoj periodici Chesterton je dočekan kao svojevrsna paradigma duhovne superiornosti katolicizma, kao, slikovito, orijaš katoličke apologetike, što je on odražavao i svojom krupnom simpatičnom fizičkom pojavom te abruptnom i polemičnom naravi. U duhovnim, filozofskim, socijalnim i političkim prevratima toga vremena on je, isticalo se, svjedočio ne konzistentnost katoličke misli, nego i misaonu slobodu i raskoš katolicizma. Njegova pojava i barokni karakter misli zrače vedrinom i optimizmom, što je uvelike odudaralo od turobnosti — slike koju su o katolicizmu javnosti nametali njegovi protivnici. Stoga su duhovitost, paradoksalnost, britka polemičnost prepoznate originalnima (iako britkosti ima u tadašnjoj hrvatskoj apologetici), s ponekom blagonaklonom kritikom nekih pretjeranosti, kojima je bio sklon. Tako su i njegove polemike sa Shawom i drugima dobile zamjetno mjesto u recepciji njegova života i djela, kao i njegova originalna zamisao da katoličku apologetiku promiče kriminalističkim pričama.

U svojevrsnoj kompilaciji ocjena i pogleda, taj »uvjereni katolik, tradicionalista u strogom smislu riječi« (Delalle), »ekstravagantni engleski pisac« (Bošković), »pjesnik, apologet, socijalni radnik« (Myr) »tačnog i dosljednog umovanja« (Podolšak), »veliki borac protiv organiziranog materijalizma, [...] velika moralna energija [...], sjajni rvač Gospoda Boga, taj lojalni, srdačni muž, prijatelj vina i opojenosti, taj bezbrižni, slobodni i veseli čovjek « (Maraković) pisao je »žestoko, živahno, s mnogo snage i zanosa « (Tomičić) djela puna »veselosti i dobre volje, baroka i paradoksa « (Rieger), što ih krase »duhovitost« (Andrić) i »humorizam, jasnoća stila, ugodno razlaganje, logičnost u dedukcijama« (Delalle). Njegova je misao »medicina naših dana « (Ćepulić), a on čovjek kojim se »trebamo ponositi i koga, još više, trebamo nasljedovati« (Myr). Ukratko, on je »najbliži idealu javnog radnika, kakovog hoće da odgoji naš katolički pokret« (Bogdan).

Zaključno, Chesterton je bio autor čiji je život i djela hrvatska katolička periodika rado isticala kao paradigmu umjetničke visine do koje se može vinuti književnost pisana u katoličkom duhu, što se tada osjećalo potrebnim isticati u okolnostima osporavanja i kritika iz krugova liberalnih i socijalističkih intelektualaca, koji su nerijetko en general nijekali katoličkim piscima sposobnost kreativnog umjetničkog stvaranja. No takvih je primjera u svjetskoj literaturi bilo moguće naći desetke, pa je važnija od toga bila paradigma Chestertona kao čovjeka koji je prije svega snagom intelekta došao do spoznaje da je istina Objave u Katoličkoj crkvi i koji je sve svoje misaone odlike stavio u službu obrane i promicanja te istine. 


\section{Literatura:}

Andrić, Josip (1936). Jedan od najvećih katoličkih pisaca: Nakon nedavne smrti engleskog pisca Gilberta Keitha Chestertona. Obitelj, 8(26), 503.

B. (1932). Jedna umjesna opaska o svjetskom razoružanju i miru. Nova revija, 11(4), 350351.

Bogdan, Ivo (1931-1932). Chesterton Gilbert Keith. Luč, 27(3), 83.

Bošković, Hijacint (1935). Chesterton o sv. Tomi. Duhovni život, 7(4), 248-251.

Chesterton, Gilbert Keith (1921). Prostota oca Browna: Modri križ. Hrvatska prosvjeta, 8(II, 1), 325-334; (II, 2), 373-378. (Preveo Antun Šimčik.)

Chesterton, Gilbert Keith (1922). G. Bernard Shaw: (Iz "Heretika"). Hrvatska prosvjeta, 9(19-20), 453-458. (Preveo Antun Šimčik.)

Chesterton, Gilbert Keith (1929). Vjetar i drveće. Obitelj, 1(45), 750.

Chesterton, Gilbert Keith (1930). Vjetar i drvlje. Hrvatska straža, 2(31), 5. (Preveo O. Sivjanović, s portretom.)

Chesterton, Gilbert Keith (1931-1932). Markiz Marne: (Iz knjige „The Secret Of Father Brown“). Luč, 27(3), 81-83; 27(4), 115-117.

Chesterton, Gilbert Keith (1935). Vjetar i drveće. Hrvatska straža, 7(253), 12.

Chesterton, Gilbert Keith (1936a). Gospodin Bernard Shaw. Obitelj, 8(34), 647-649. (Preveo Antun Šimčik.)

Chesterton, Gilbert Keith (1936b). Grimizna vlasulja. Obitelj, 8(26), 505-509 i 512.

Chesterton, Gilbert Keith (1936c). Kriminalna novela: Salata pukovnika Craya. Obitelj, 8(28-29), 544-546; 8(30), 572-574. (Preveo Vlado Sironić.)

Chesterton, Gilbert Keith (1936d). Zašto sam katolik? Obitelj, 8(27), 532-533.

Chesterton, Gilbert Keith (1939a). Čas Sv. Tome. Hrvatska straža, 11(83), 14.

Chesterton, Gilbert Keith (1939b). Približavanje tomizmu: G. K. Chesterton o filozofiji Sv. Tome Akvinskog. Hrvatska straža, 11(175), 4-5.

Chesterton, Gilbert Keith (1939c). G. B. Shaw, koga Nijemci rabe u svojoj propagandi: G. K. Chesterton o Shawu i njegovu gledanju na svijet, život i pojave u društvu. Hrvatska straža, 11(263), 5 .

Chesterton, Gilbert Keith (1939d). Zašto sam postao katolik? Duhovni život, 11(5), 301306.

Chesterton, Gilbert Keith (1945). Znanost i ludost. Nedjelja, 17(2), 2-3; 17(3), 5; 15(4-5), 4-5.

Čuvalo, Ljubo (1934-1935). Katolički književnici u Engleskoj iza Shakespearea. Stopama otaca, 101-108.

Ćepulić, Drago (1939). G. K. Chesterton: otac zapadne kulture (naklada "Istine”, Zagreb 1939). Hrvatska smotra, 7(7-8), 423-424.

Delalle, Ivo (1927). Filozofija Chestertona: Rim, u svibnju: (Prikaz knjige "L'Ortodossia”). Narodna politika, 10(29), 2-4.

Gahs, Aleksandar (1929). Engleski katolici i njihove organizacije. Život, 10(2), 88-95.

Hoško, Franjo Emanuel; Ćošković, Pejo; Kapitanović, Vicko (ur.) (2010). Hrvatski franjevački biografski leksikon. Zagreb: Leksikografski zavod Miroslav Krleža.

Krišto, Jure (2004). Hrvatski katolički pokret: 1903.-1945. Zagreb: Glas Koncila.

Lončarević, Vladimir (2005). Književnost i Hrvatski katolički pokret. Zagreb: Alfa.

Lončarević, Vladimir (2006). Bilješka o piscu. U: Drago Ćepulić, Život i duh: Studije i eseji (str. 269-270). Zagreb: Glas Koncila. 
Lončarević, Vladimir (2009). Bilješka o autoru. U: Ljubomir Maraković, Katolički idealizam i realizam: Kritike, studije, intervjui, članci (str. 330-332). Zagreb: Glas Koncila.

Lončarević, Vladimir (2011a). Ivan Delalle — poeta starina. Glas Koncila, 50(27), 21.

Lončarević, Vladimir (2011b). Josip Blažina Jožčenko - humorist i posljednji urednik katoličkog dnevnika. Glas Koncila, 50(25), 21.

Lončarević, Vladimir (2011c). O autoru. U: Josip Andrić, Hrvatstvo i katolička kulturna obnova: Članci i studije (str. 259-262). Zagreb: Glas Koncila.

Lončarević, Vladimir (2011d). Socijalna i politička misao Stjepana Podolšaka. Glas Koncila, 50(37), 21.

Lončarević, Vladimir (2014). Ivo Bogdan: Domagojstvo u sjeni politike. Glas Koncila, 53(35), 21.

Lončarević, Vladimir (2015). Vladimir Sironić: "Meni je glavno da sam kršćanin”. Glas Koncila, 54(49), 21.

Lončarević, Vladimir (2016). "Široko pero” Antuna Šimčika. Glas Koncila, 55(26), 17.

Lončarević, Vladimir (2017). Stjepan Tomičić — od Hrvatske straže do ÖRF-a. Glas Koncila, 56(42), 21.

Maraković, Ljubomir (1921). G. K. Chesterton. Hrvatska prosvjeta, 8(2), 379.

Miščin, Daniel (2011). O autoru. U: Hijacint Bošković, Suvremenost tomističke baštine: Rasprave i članci (str. 252-253). Zagreb: Glas Koncila.

Myr (1937). Gilbert Keith Chesterton: S portretom. Glasnik Sv. Ante Padovanskoga, 32(12), 363-366.

Pearson, Hesketh (1936). Shaw contra Chesterton. Obitelj, 8(34), 645-646 i 656. (S portretom G. K. Chestertona i fotografijom B. Shawa u Kotoru.)

Peričić, Helena (1997). Bibliografija hrvatske kritike o engleskoj književnosti (1914-1940). Filologija, 28, 47-71.

Peričić, Helena (2007). Razotkrivanje nepoznatog ili...: Manje poznate pojedinosti iz recepcije engleske književnosti u hrvatskoj kritici 1918.-1940. Građa i rasprave o hrvatskoj književnosti i kazalištu, 33(1), 356-372.

Podolšak, Stjepan (1922). Obraćenje G. K. Chestertona. Hrvatska prosvjeta, 9(19-20), 468-472.

R. (1940). G. K. Chesterton: otac zapadne kulture Sv. Toma Akvinski (preveo s engleskog Josip Blažina). Luč, 35(4-6), 14.

Rieger, Vilko (1930). G. K. Chesterton. Nedjelja, 2(3), 3-5; 2(4), 4-6.

S. (1927). Besposlena žena i moderno društvo: Prikaz radio-rasprave u Londonu 27. 1. 1927. između novinarke Rhonda i pisca Gilberta Keith Chestertona pod predsjedanjem B. Shawa. Život, 8(5), 289-292.

Stuparić, Darko (ur.) (1997). Tko je tko u NDH: Hrvatska 1941.-1945. Zagreb: Minerva.

Tomičić, Stjepan (1935). G. K. Chesterton o Sv. Tomi Akvinskom. Hrvatska straža, 7(125), 5.

Tomičić, Stjepan (1936). Ličnosti i vjekovi. Hrvatska prosvjeta, 23(1-2), 64-68.

Torbarina, Josip (1942). Chesterton, Gilbert Keith. U: Mate Ujević (ur.), Hrvatska enciklopedija: 3: Boj-Cle (str. 722). Zagreb: Hrvatski izdavalački bibliografski zavod.

Ujević, Mate (ur.) (1959). Bibliografija rasprava, članaka i književnih radova: I. Nauka o književnosti: 3. Historija stranih književnosti (str. 8 i 612). Zagreb: Jugoslavenski leksikografski zavod.

Uredništvo (1922). Obraćenje G. K. Chestertona. Narodna politika, 5(210), 2.

Uredništvo (1923). Gilbert-Keith Chesterton: (Engleski Solovjev). Život, 4(4), 196-205.

Uredništvo (1936). G. K. Chesterton. Hrvatska straža, 8(143), 4-5. 
Uredništvo (1937). Šta je veliki književnik Chesterton našao u Katoličkoj crkvi. Nova revija, 16(1), 53-54.

Uredništvo (1942). [Moto.] Luč, 37(6-7), 162.

Verboye, J. (1936). Lik G. K. Chestertona. Obitelj, 8(26), 504.

Vuco, Božo (1928). Slavni engleski obraćenik G. K. Chesterton i ateizam. Nova revija, 7(1) $77-78$.

The Reception of G.K. Chesterton in Croatian Catholic Periodicals 1921-1945

Vladimir Lončarević*

\section{Summary}

Since 1903, when the Croatian Catholic Movement was developing under the auspices of the Bishop of Krk, Antun Mahnic, it was accompanied by a proliferation of Catholic publications, the first of which was The Croatian Guard for a Christian Educational System (Hrvatska straža za kršćansku prosvjetu), issued in 1903, the first Croatian journal of philosophy. This movement promoted the rechristianization of Croatia, and so, converts to Catholicism among the European intelligentsia, whose numbers steadily rose since the beginning of the 19th century, were frequently highlighted in Croatian Catholic publications. Namely, they were to be a sign and message of the spiritual renewal of Catholicism in Europe. Moreover, Catholicism was found palatable to the intellectual elite which fact was often disputed within various circles of the liberal or socialist i.e. communist intelligentsia. Among the aforementioned converts were a number of English-speaking intellectuals, one of whom was Gilbert Keith Chesterton. Articles were published about him between 1921 and 1945 when, due to communist repressive measures, the issuing of Catholic publications was suspended. Texts can be divided into two corpuses: a) articles on Chesterton (biographies, interpretations, book reviews) and b) translations into the Croatian language (novellas, essays, excerpts from books). Chronologically, articles are grouped mostly around two key events, and these are Chesterton's conversion and his death.

Key words: G. K. Chesterton, reception, conversion, Catholic periodicals, 1921-1945

* Vladimir Lončarević, Ph.D., Senior Research Associate, Office of the President of the Republic of Croatia. Address: Pantovčak 241, 10000 Zagreb, Croatia. E-mail: vladimir.loncarevic31@gmail.com 